\title{
ASCENSÃO E CRISE DO POLICIAMENTO COMUNITÁRIO
}

por Rodrigo Figueiredo Suassuna*

HERBERT, Steve. Citizens, cops and power: recognizing the limits of community. Chicago: University of Chicago Press, 2006. 180 p.

O livro de Steve Herbert tem como objeto a relação entre polícia e comunidade nos bairros da região oeste de Seattle. Partindo de tal análise, o autor também verifica as possibilidades da comunidade como forma de associação política. Herbert busca nos conceitos normativos de comunidade, policiamento comunitário e relação Estado-comunidade, o referencial para verificar como essas idéias estão presentes tanto nas narrativas dos moradores locais, como nas práticas culturais dos policiais que atuam em West Seattle. Policiamento comunitário é entendido como o conjunto genérico de programas que têm os seguintes objetivos: a) fortalecer os elos entre polícia e cidadãos; e, b) descentralizar a atividade policial.

Além dos conceitos normativos, provenientes da teoria política, o referencial teórico do estudo passa também pela verificação empírica do conceito de comunidade como forma urbana de organização, passando pela verificação dos fatores que favorecem ou dificultam o seu desenvolvimento. Esse aspecto leva ao reconhecimento do pressuposto de que, no espaço urbano, tende a existir uma grande identificação entre a idéia de comunidade e a idéia de bairro (neighborhood).

A forma escolhida para a análise foi um estudo de caso qualitativo, envolvendo os bairros do oeste de Seattle, e que foram

* Mestrando em Sociologia na Universidade de Brasília (UnB). 
agrupados pelo autor em áreas demograficamente homogêneas. $\mathrm{O}$ estudo de caso envolveu duas partes que se desenvolveram concomitantemente. A primeira delas baseou-se em entrevista semiaberta com moradores da região, cuja seleção foi feita no interior dos grupos, dando-se mais ênfase à escolha de respondentes provenientes de grupos com maiores taxas de criminalidade e menor renda (aspectos que se correlacionam na região analisada). Na segunda parte desenvolveu-se uma observação participante das atividades de policiamento realizadas no local, fossem elas de policiamento comunitário ou não.

Assim é que, no primeiro capítulo, são analisadas as narrativas dos moradores a respeito do que eles entendem por comunidade. As visões normativas sobre a categoria comunidade, de acordo com Herbert, podem ser densas (thick) ou leves (thin). Entre as perspectivas que o autor chama de densas, há a afirmação de que a comunidade representa o reforço de um sistema de valores que assim estrutura e organiza a vida de pequenas sociedades, mantendo-lhes a coesão. Esta perspectiva pode, alternativamente, ver a comunidade como um grupo inclusivo e politicamente efetivo. Já a visão leve defende a limitação do poder da comunidade sobre o indivíduo. A partir das narrativas analisadas, Herbert conclui que a concepção dos moradores de West Seattle não é nem densa nem leve, estando ligada à segurança física e ontológica: os moradores vêem a comunidade como relacionada à possibilidade de ajuda mútua em caso de necessidade, e à familiaridade entre vizinhos como forma de suporte afetivo. Assim, os fatores que favorecem tais aspectos, favorecem também a organização em comunidade.

No capítulo 2, o autor analisa as possibilidades da associação comunitária como forma de atuação política, a partir das narrativas dos moradores. Eles citam como obstáculos à comunidade a cultura individualista, a heterogeneidade cultural - entre bairros e no interior dos bairros -, a transitoriedade dos moradores, e o medo da criminalidade. Além disso, as narrativas trazem a idéia de que a burocracia estatal cria obstáculos significativos às demandas da comunidade, de modo que há uma seleção destas pela exigência de 
um elevado capital cultural, ou seja, exige-se uma cultura e uma escolaridade próprias das classes mais altas. A conseqüência disso seria, primeiramente, a seleção de lideranças comunitárias por seu capital cultural, e não por sua representatividade. Em segundo lugar, além desse problema de representatividade, isso proporciona uma desigualdade entre as comunidades na hora de estabelecer as demandas junto ao Estado, favorecendo aquelas com maior vantagem econômica.

O capítulo 3 apresenta as formas como as práticas culturais da polícia de Seattle refletem concepções normativas acerca da relação entre polícia e comunidade. Tais concepções derivam das formas pelas quais o Estado adquire sua legitimidade em sua relação com os atores da sociedade civil. O autor fala de três conjuntos de idéias: 1) a de que o Estado deve ser subserviente às demandas da comunidade; 2) a de que deve haver uma separação entre Estado e comunidade, seja ela estabelecida por meio da legalidade, seja por meio da divisão de competências profissionais entre esses dois entes; e, 3) a de que o Estado é capaz de construir a idéia de comunidade pela forma como canaliza suas demandas e, também, por meio de ideologias. $\mathrm{O}$ autor mostra como todas essas idéias estão presentes nos projetos de legitimação da polícia, ressaltando, contudo, as tensões que existem entre essas concepções na prática. Tais tensões são capazes de comprometer a própria legitimidade buscada pela polícia.

O quarto capítulo trata dos fundamentos culturais da polícia e suas implicações para o projeto de policiamento comunitário. $\mathrm{O}$ primeiro deles, para o autor, seria o gosto pela aventura que os policiais desenvolvem por lidar com situações de perigo. Isso tem como conseqüência a desvalorização do trabalho comunitário, estigmatizado como "assistência social" e como "feminino"; além disso, o comportamento intempestivo torna-se aceito entre os policiais, o que obstrui a relação com os cidadãos. Uma segunda característica da cultura policial é o esforço de autopreservação - expresso de forma imprecisa pelos agentes de polícia -, que os leva a adotar procedimentos de necessidade duvidosa e, portanto, ilegítimos aos olhos do cidadão. Além disso, devido a esse esforço 
pela autopreservação, os policiais resistem à proximidade física requerida pelo policiamento comunitário. $\mathrm{O}$ terceiro aspecto da cultura policial é a reivindicação de autoridade por parte dos policiais. Tal autoridade é vista como necessária para dominar situações de perigo, mas tende a ser um empecilho para uma relação igualitária entre policiais e membros da comunidade. Uma quarta característica seria a cultura individualista das organizações policiais, o que dificulta o desenvolvimento de estratégias coletivas, tais como o policiamento comunitário. Finalmente, Herbert fala da narrativa segundo a qual o combate à criminalidade passa, principalmente, pela prisão dos criminosos. Isso daria à polícia um papel preponderante nos programas de segurança pública, e à comunidade, um papel passivo. Os fundamentos culturais da polícia permitem, assim, compreender a resistência dos policiais aos programas comunitários.

No capítulo 5, o autor analisa a narrativa dos residentes de West Seattle sobre o papel da polícia. Ficam claros a empatia e o reconhecimento do trabalho policial, por parte dos residentes. O autor mostra também como as três perspectivas já mencionadas sobre a relação entre comunidade e Estado, da mesma forma que marcam as práticas policiais, estão presentes também nas narrativas dos cidadãos. Contudo, existem aspectos conflitivos entre essas concepções. O autor cita, por exemplo, a idéia de que a ordem legal, por um lado, fundamenta os direitos do cidadão junto à polícia, mas, por outro, restringe a resposta da corporação a problemas que a comunidade considera importantes. Além disso, as afirmações de autoridade profissional por parte dos policiais fundamentam a autonomia da profissão, mas, por outro lado, dificultam as interações entre policiais e cidadãos. Cita-se ainda, a partir da narrativa dos moradores, o problema da canalização das demandas dos cidadãos sob um formato particular, e a queixa de que estas são sempre questionadas quanto à sua precisão. Finalmente, Herbert trata do estigma que certos bairros sofrem dos policiais que, partindo de uma construção moralista, classificam determinados locais como violentos. Tais aspectos mostrariam como as expectativas de participação política dos residentes entram em conflito com os projetos de legitimação levados adiante pela polícia. 
O capítulo 6 está reservado para a discussão da principal conclusão do livro: a comunidade é excessivamente leve do ponto de vista político. Para o autor, a idéia de comunidade não oferece suporte para responsabilidades políticas, e as demandas comunitárias não encontram ressonância no aparato estatal. Isso dá margem a uma série de implicações, sendo a principal delas a de que o modelo baseado no policiamento comunitário deve ser abandonado.

Duas observações podem ser feitas quanto às possíveis limitações do livro. Primeiramente, a teorização sobre as especificidades da polícia diante de outros órgãos do Estado ocupa uma posição periférica na análise. Assim, é constante no estudo a identificação entre polícia e Estado, e uma perspectiva da relação entre polícia e cidadão como uma expressão da relação Estado-sociedade. O próprio texto mostra, em certas partes, a busca do policial pela construção de sua identidade profissional e organizacional, mas isso assume uma importância pontual na argumentação do autor, não repercutindo na maior parte das generalizações empíricas propostas no estudo. Basta observar a imprecisão gerada ao se generalizar as possibilidades do policiamento comunitário para as possibilidades da relação entre comunidade e Estado.

Segundo, apesar de apresentar uma construção teórica significativa sobre a relação entre Estado e comunidade, o estudo traz também uma conclusão normativa e negativista sobre policiamento comunitário, insistindo sobre a necessidade de ele ser abandonado como modelo. Entretanto, muitas idéias trazidas pelo próprio texto, dando conta da complexidade envolvida no policiamento comunitário, fornecem elementos inexplorados como política pública, e que permitem pensar na reestruturação desse policiamento. É possível, por exemplo, pensar uma "profissionalização subserviente" da atividade policial, ou seja, em um projeto de legitimação que fosse baseado em uma cultura profissional balizada pela avaliação dos cidadãos. Outra possibilidade poderia ser uma reestruturação burocrática, de modo que a absorção de demandas contemplasse o ideal de comunidade visto como mais adequado pelos cidadãos. 